\title{
Development of Mathematics Learning Devices Through Problem Based Learning Models to Improve Problem Solving Mathematics Ability Students SMP Swasta Salsa
}

\author{
Reziono Pratama \\ Mathematics Education Program, Post Graduate Program \\ State University of Medan, Indonesia \\ Pargaulan Siagian \\ Mathematics Education Program, Post Graduate Program \\ State University of Medan, Indonesia \\ Nerli Khairani \\ Mathematics Education Program, Post Graduate Program \\ State University of Medan, Indonesia
}

\begin{abstract}
ABSTRACK
This study aims to 1) Produce products that are developing a problem-based learning tool that is valid, practical and effective in improving mathematical problem solving abilities; 2) Analyzing the improvement of students mathematical problem solving abilities in the application of problem-based learning tools. This type of research is the development using a 4-D model. The results showed that: (1) Product validity in the form of RPP, student book, LAS, and mathematical problem solving ability tests included aspects of format feasibility, language and content in a valid category; (2) Analysis of the practicality of the problem learning device developed, shows the results: a) the assessment of experts/practitioners states can be used with little revision or without revision and; b) the feasibility of learning devices in the class is included in the minimum high category and has increased by 0.16 ; $(3)$ the effectiveness of the product shows: a) The completeness value of student learning outcomes increases by $10 \%$; b) Student activity shows that all categories are at the specified ideal time tolerance interval; c) and the positive response of students is $85.7 \%$.
\end{abstract}

Keywords: Development of Mathematics Learning Devices, 4-D Models, Problem-Based Learning, Problem Solving Mathematics Ability

\section{BACKGROUND}

Implementation of the 2013 curriculum that directs teachers to carry out the 21st century learning paradigm expected to help students to make observations, ask questions, reason, and communicate what they have acquired or known. This can be realized through effective mathematics learning in schools. Mathematics subjects are always taught in each education unit and at each grade levelwith a greater portion of class hours than other subjects. This shows how important mathematics is. As according to Abdurrahman (2012:202) who argued that "Everyone must learn mathematics because mathematics is a means to solve problems of everyday life".

There are five reasons why mathematics needs to be studied, namely: 1) mathematics is a clear and logical means of thinking, 2) a means of solving problems of everyday life, 3) means of recognizing relationship patterns and generalizing experiences, 4) a means to develop 
creativity, and 5) means to increase awareness of culture". National Council of Teachers of Mathematics (NCTM) states (2000:29), there are 5 important process standards in mathematics learning, namely: problem solving, reasoning, communication, connections and representation. According to NCTM, problem solving is the main thing in learning mathematics. With mathematical problem solving, students can form a way of thinking, accustomed to being diligent and having curiosity, and able to solve new problems in everyday life wherever they are .

Liljedahl (2016) stated that mathematical problem solving has long been seen as an important aspect of mathematics, teaching mathematics, and learning mathematics. Developing problem solving skills is one of the goals of mathematics learning that is considered important. Das, Ranjan, and Chandra (2013) explained that problem solving plays an important role in learning and teaching mathematics, by solving problems, students can improve their thinking skills, implement procedures, and deepen conceptual understanding. Ozturk and Guven (2016:411) said, "Problem solving skills have important objectives in contemporary curriculum." This implies that problem solving abilities have an important place in the main objectives of the curriculum. Therefore mathematical problem solving is very important in mathematics learning.

But the reality in the field of mathematical problem solving skills in junior high is still low. Based on the problem solving ability test conducted at SMP Swasta Salsa, 76.17\% of the students of class VII had low problem-solving abilities, namely in the category below B-. This was also marked by the results of the interviews, students said that when they did the tests, they found it difficult and did not understand when they wanted to do the completion step even though they already knew what was known and what was asked in the matter.

One of the causes of the low mathematical problem solving ability of students is that the learning model used is less effective. As revealed by Intaros and Pimpaka (2014:2) that in learning students must be encouraged to do problem solving, in addition, start a class with problems that are designed according to the experience of students or what has been learned. Through this explanation it is clear that students' mathematical problem solving skills can be trained by the application of effective learning models.

In addition to applying the learning model, planning and designing quality learning tools is also important in training students problem solving skills. Quality learning tools provide convenience and can assist teachers in preparing and carrying out teaching and learning activities in the classroom, so that the teaching materials used make it easy for students to learn mathematics (Sulistyaningsih, 2013:2).

There are many learning models that can be used in an effort to develop mathematical abilities, one of the learning models recommended in the 2013 curriculum curriculum book that is in line with mathematical characteristics is a problem-based learning model. As according to Saragih (2007:9) students soft skills such as the ability to cooperate, communicate, enthusiasm in carrying out tasks, managing time, developing logical thinking, and instilling moral values, noble character and morals, can be taught and trained with problem-based learning models.

Research conducted by Salimah Angreiny (2015:214) stated that problem-based learning can improve students problem solving and mathematical communication skills. Based on the explanation above, researchers have developed a valid, practical and effective problem-based mathematics learning tool to improve students mathematical problem solving skills in SMP Swasta Salsa. 
Shapiro (2011:15) reveals the advantages of problem solving abilities, namely when solving problems, students learn to apply their mathematical skills in new ways, develop a more understanding of mathematical ideas and get a sense of experience "Being a mathematician". With this success, will bring a sense of achievement, enjoyment, and perhaps more interest in mathematics. By continuing to repeat problem solving activities can increase self-confidence, build stamina, and perseverance so that the experiences they get by solving problems can be saved for future use.

According to Polya (1981) to solve a problem there are four steps that can be done, namely: (1) understanding the problem, (2) devising a plan, (3) implementing the plan (carrying out the plan), (4) checking the process and results (looking back) [14]. At the step of understanding the problem, questions are asked such as: "What is known about the problem?, What was asked in the matter?". In the completion planning step, asked questions such as: "Has there ever been a problem like this that was previously resolved?, Can the old experience be used in the current problem?". In the step of carrying out the plan a question is asked "Check that each step is correct?, How to prove that the steps chosen are correct?". In the step of checking the results and processes, questions are asked "Can you check the rebuttal?, Can the answer be sought in another way?" Thus, in this study the four indicators above are used to see the level of students' problem solving abilities.

Problem-based learning is more than an effective way to learn certain knowledge. He can help students build skills throughout their life in solving problems, collaborating in teams and communicating (Amir, 2010:13). Problem-based learning also involves the presentation of authentic and meaningful situations that serve as a basis for student investigation and investigation (Arends, 2008:41). The syntax of problem-based learning can be seen in the following table 1.

Table 1. Syntax of Problem Based Learning Models

\begin{tabular}{|l|l|}
\hline \multicolumn{1}{|c|}{ Step } & \multicolumn{1}{|c|}{ Teacher's Activity Steps } \\
\hline Problem orientation & $\begin{array}{l}\text { Explain learning objectives, explain the logistics } \\
\text { needed, and motivate students to engage in } \\
\text { selected problem solving activities. }\end{array}$ \\
\hline $\begin{array}{l}\text { Organizing students for } \\
\text { learning }\end{array}$ & $\begin{array}{l}\text { Helping students define and organize learning } \\
\text { tasks related to the problem. }\end{array}$ \\
\hline $\begin{array}{l}\text { Guiding individual / } \\
\text { group inquiry }\end{array}$ & $\begin{array}{l}\text { Encouraging students to gather appropriate } \\
\text { information, carrying out experiments, to get } \\
\text { explanations and problem solving }\end{array}$ \\
\hline $\begin{array}{l}\text { Developing and } \\
\text { presenting work }\end{array}$ & $\begin{array}{l}\text { Helping students in planning and preparing } \\
\text { appropriate works such as reports, videos, } \\
\text { models, and helping them to share assignments } \\
\text { with their friends }\end{array}$ \\
\hline $\begin{array}{l}\text { Analyze and evaluate } \\
\text { the problem solving } \\
\text { process }\end{array}$ & $\begin{array}{l}\text { The teacher helps students to reflect or evaluate } \\
\text { their investigations and the processes they use. }\end{array}$ \\
\hline
\end{tabular}

Eggen and Kauchak (2012:307) mention problem based learning is a set of teaching models that use problems as a focus for developing problem solving skills. Furthermore, Arends (2008:41) stated that the problem-based learning model is a learning model where students work on authentic problems with the intention to compile their own knowledge, develop inquiry and higher-order thinking skills, develop independence and confidence. Problem-based learning is the use of various kinds of intelligence needed to confront real-world challenges, 
the ability to deal with everything new and existing complexity (Rustam, 2011:232). From some of the opinions above, it can be concluded that what is meant by problem-based learning is a series of processes to understand the concepts and principles of a material starting from work and learning to real situations or problems that are given, through investigation, inquiry, modeling and problem solving then students develop concepts or principles with their own abilities that integrate skills and knowledge that have been understood before.

\section{RESEARCH METODH}

This type of research is research \& development (R \& D) refers to the development model procedures according to Thiagarajan, Semmel and Semmel, namely the 4-D (four D models) model which consists of 4 stages, namely define, design, develop and disseminate. Subjects in this study were students of Salsa Schools in Junior High School Percut Sei Tuan at Class VII-A and VII-B with 21 students in the $2017 / 2018$ school year. The object in this study is a mathematics learning tool in the form of learning implementation plans, student books, student worksheets, and tests of mathematical problem solving abilities.

To see the validity of learning tools obtained from the validator examination (assessment) and the results of the assessment of research instruments meet valid criteria. Learning devices are said to be valid if three of the five validators state valid. Then the practicality of the learning device is seen from two aspects, namely: (1) the assessment of the expert / practitioner of the learning device that was developed stated that it could be used with little revision or without revision; (2) The results of observing the feasibility of learning equipment in the class are included in the level of high or very high level. And measuring the effectiveness of learning devices seen from four aspects, namely: classical learning completeness, student response, and learning time. Mathematics learning devices are said to be effective if two of the four aspects of effectiveness are achieved. The aspects of effectiveness are: (1) classical student learning completeness; (2) the response of students with a minimal strong category; (3) the percentage of ideal time for student and teacher activities with ideal criteria 4 of 6 aspects of the category are fulfilled.

To see the improvement of students mathematical problem solving abilities classically, based on the results of the percentage of students completeness in trial I and trial II after being treated with problem-based learning, it was analyzed by comparing the percentage of students classical completeness obtained from the results of the posttest test I and posttest trial II. Improvement of students mathematical problem solving skills can also be seen from each indicator compared to each trial and between trials.

\section{Validity of Learning Devices}

\section{RESULTS AND DISCUSSION}

Validation of learning devices includes content, format, language and compatibility with problem-based learning models. The results of expert validation of learning devices are described in detail in Table 1 below

Table 2. Summary of Learning Device Validation Results

\begin{tabular}{|l|c|c|}
\hline \multicolumn{1}{|c|}{ The object being assessed } & $\begin{array}{c}\text { Average value of } \\
\text { Total Validity }\end{array}$ & $\begin{array}{c}\text { Validation } \\
\text { Level }\end{array}$ \\
\hline Lesson Plan & 4,46 & \\
Student Book & 4,43 & Valid \\
Student Worksheet & 4,40 & \\
\hline
\end{tabular}


Based on table 2 above, obtained the average total validity of each learning device is at intervals: $4 \leq \mathrm{Va}<5$ it can be said that the developed learning device is valid. Instrument validation is focused on content, language and question writing, conclusions with the Problem Based Learning (PBM) model. Based on the validation results of the instrument through the validator that is valid (V) with several items that must be revised small (RS) and also there are items that are stated without revision (WR). So that through the validator's suggestion then the instrument is revised.

After validating through the validator, then the instrument is tested to see the level of validity and reliability. Based on the calculation of the moment product correlation obtained valid question instrument with high interpretation and obtain reliable keofisien of 0.701 . Thus the validation of learning devices is declared valid and feasible to use.

\section{Practicality of Learning Devices}

Analysis of the practicality of the learning tools developed is seen from 2 (two) aspects, namely: (1) assessment of experts / practitioners of learning devices and; (2) results of observations of the implementation of learning devices. Based on mastery of theory and experience, experts and practitioners state that problem-based learning tools can be used with little revision. Then from the results of the analysis of the observational observation data the learning device was concluded that the achievement of the level of implementation of the learning tools in test 1 and trial 2 was included in the high category which meant that the device was said to be practical or applicable. The average value of observing the implementation of learning tools for each meeting is shown in Table 3 below.

Table 3. Average Observation Value of Implementation

\begin{tabular}{|c|c|c|c|c|c|}
\hline \multirow{2}{*}{ Trials } & \multicolumn{3}{|c|}{$\begin{array}{c}\text { Meeting of } \\
\text { Learning }\end{array}$} & \multirow{2}{*}{$\begin{array}{c}\text { Total } \\
\text { Average }\end{array}$} & Results \\
\cline { 2 - 4 } & 1 & 2 & 3 & $\overline{P_{3}}$ & \\
\hline I & 3 & 3 & 3,8 & 3,26 & High (Practical) \\
\hline II & 3 & 3,5 & 4 & 3,5 & High (Practical) \\
\hline
\end{tabular}

Based on table 3 , it was found that the average value of observation of the feasibility of learning devices in test 2 was 3.26 and trial 2 was 3.5 and was in the high category $(3 \geq \bar{P} \geq 4)$. The average increase in the implementation of learning devices is 0.25 from each trial period. Thus it can be concluded that, learning tools that are developed are practical and applicable.

\section{fectiveness of Learning Devices}

Indicators of the effectiveness of learning devices are determined by referring to three criteria, namely; (1) completeness of learning calcically; (2) the ideal activity time of students, and; (3) positive response of students. From the results of the research in Trial 1, there are two criteria that do not meet the requirements of classical learning completeness and student response so that revisions to the learning device are carried out. Weaknesses are found in student books and student worksheets so that they are addressed by making revisions. After the revision was made, the learning tool was tried again in a different class. The results of data analysis of student completeness in trial 1 and trial 2 can be seen in table 4 below. 
Table 4. Classical Learning Completeness in Each Trial

\begin{tabular}{|c|l|c|c|}
\hline \multirow{2}{*}{ Trials } & \multicolumn{1}{|c|}{ Results } & $\begin{array}{c}\text { The Number } \\
\text { of Students }\end{array}$ & $\begin{array}{c}\text { Percentage } \\
(\%)\end{array}$ \\
\hline \multirow{2}{*}{ I } & Complete & 16 & 76 \\
\cline { 2 - 4 } & Not Complete & 5 & 24 \\
\hline \multirow{2}{*}{ II } & Complete & 18 & 86 \\
\cline { 2 - 4 } & Not Complete & 3 & 14 \\
\hline
\end{tabular}

From table 4, it can be seen that classical learning completeness in trial 2 is $86 \%$, and has met the minimum completeness requirement. Besides that, classical learning completeness also increased by $10 \%$ in the second trial. For student responses also experienced an increase of $10 \%$ in trial 2 and student activity data showed all categories of activities were at the specified ideal time tolerance interval. So it can be said that student activity has been effective. Thus the learning device has met three effectiveness criteria.

After the valid, practical and effective criteria are met at the end of the trial 2 , the final device is obtained. The next step is to conduct a limited distribution in the form of the distribution of the final device to the MGMP forum at SMP Negeri 7 Percut Sei Tuan. Submission of learning activities to the MGMP forum with the hope that the mathematics teachers who are members of the forum can apply the learning tools to the next learning.

\section{Increased Mathematical Problem Solving Ability}

The analysis of the improvement of students mathematical problem solving ability with the developed tools based on the problem was carried out from trial 1 to trial 2 . The average test results of students' mathematical problem solving abilities in trial 1 and trial 2 can be seen in table 4 below.

Table 5. Results of An Improved Mathematical Problem Solving Analysis

\begin{tabular}{|l|c|c|c|}
\hline Indicator & Post Test 1 & Post Test 2 & Enhancement \\
\hline $\begin{array}{l}\text { Understanding the } \\
\text { Problems }\end{array}$ & 2,57 & 2,71 & 0,14 \\
\hline Devising a Plan & 2,29 & 2,48 & 0,19 \\
\hline Implementing the Plan & 2,02 & 2,17 & 0,15 \\
\hline $\begin{array}{l}\text { Checking the Process and } \\
\text { Results (looking back) }\end{array}$ & 0,74 & 0,86 & 0,12 \\
\hline Rata-rata & 1,9 & 2,05 & 0,15 \\
\hline
\end{tabular}

From table 5 shows the average increase in mathematical problem solving ability of 0.15 . Meanwhile, the highest indicator improvement of students' mathematical problem solving ability is on the indicator of understanding the problem of 0.19. And the increase in the indicator of the lowest students' mathematical problem solving ability is on the indicator understanding the problem that is equal to 0.12 .

\section{DISCUSSION}

Based on the results of the posttest analysis the students problem solving abilities in the I and II trials showed that the students problem solving abilities increased. The improvement of problem solving abilities can be seen from the average results of post test problem solving abilities obtained by students. The improvement of students problem solving skills is also seen in each indicator of problem solving abilities, namely on indicators of understanding the problem, planning a solution, implementing a settlement plan and re-examining the process 
and results. This shows that the use of problem-based learning tools developed has an impact on improving students mathematical problem solving abilities. The results of this study were reinforced by Muchayat (2011:202) in his journal about the development of mathematical learning devices with ideal problem solving strategies charged with catholic education indicating that the products developed can improve students' problem solving abilities. This can be seen from the learning outcomes of students who use products with ideal problem solving strategies better than student learning outcomes in conventional groups. So that it can be concluded that the problem-based learning device developed can improve students problem solving abilities.

Correspondingly, the research conducted by Amalia, Surya and Syahputra (2017:3405) revealed that students who are taught using PBL models have better mathematical problem solving abilities, the use of PBL in the teaching and learning process is effective in improving mathematical problem solving skills for students. This is because when teaching with PBL, students are guided to find their own answers by following the steps of the PBL model. Various dimensions and benefits of problem-based learning for students include students will increase their problem solving skills, easier to remember, increased understanding, increased knowledge relevant to the world of practice, encourage them full of thought, build leadership skills and, cooperation, learning skills, motivate students , and activate student activity (Amir, 2010:27). Related to this, the results of Syahputra and Surya's (2017:84) research also revealed that by applying the PBL model learning activities went well as expected. Students actively observe learning material and ask questions in their study groups. Students actively try to solve the problem given. Students can link the information they get from the problem given. Students actively communicate their opinions to their study groups. Significantly, we cannot see students doing many things outside of learning.

Vygotsky (Rustam, 2011:244) revealed, learning based on problems is an effort to link new information with the cognitive structure that has been possessed through learning activities in its social interaction. Vygotsky (Arends, 2008:47) added that social interaction with other people both teachers and peers refers to constructing new ideas and improving students' intellectual development. With the right challenges and help from more capable teachers and peers, students will advance to the zone of proximal development where new learning takes place. The opinion above, directs students to be active in groups and handle their tasks so that learning in the classroom is effective which in turn will have an impact on student learning outcomes.

\section{CONCLUSION}

Based on the results of the analysis and discussion in this study, several conclusions were put forward (the quality of problem-based learning device products) as follows:

1. Problem-based learning devices developed include learning implementation plans, student books, student worksheets and tests of mathematical problem solving skills declared valid.

2. Analysis of the practicality of problem-based learning tools developed in terms of two aspects, namely: (a) the assessment of experts / practitioners of developed learning devices can be used with little revision or without revision; (b) the results of observations on the implementation of classroom learning equipment are included in the high category. The average increase in the value of observation of the implementation of learning devices is 0.25 .

3. Product effectiveness

a. The results of the trial 1 obtained the student's completeness value of $76 \%$ while for trial 2 was $86 \%$, thus the completeness value of student learning outcomes increased by $10 \%$. 
b. The results of student activity data analysis showed that all student activity categories ( 6 categories) were at the specified ideal time tolerance interval.

c. Sis response The results show that the subject under study provides a positive response to the components and learning activities.

4. Improvement of students mathematical problem solving ability occurs in all indicators, namely the first indicator to understand the problem of 0.14 . Whereas in the second indicator that is planning to solve the problem of 0.19. And in the third indicator that is implementing a problem solving plan of 0.15 . The fourth indicator is to re-examine the process and the results of 0.12 . Thus overall it can be concluded that students mathematical problem-solving abilities increase.

\section{References}

Abdurrahman, M. 2012. Children with learning difficulties. Jakarta: Rineka Cipta.

Angreiny, Salimah. 2015. Development of Problem Based Learning Devices to Improve Students' Problem Solving and Mathematical Communication Capabilities MTs Madinatussalam Sei Rotan. Thesis Mathematics Education.

Medan: Perpustakaan PPs UNIMED.

Amalia E., Surya, E., Syahputra, E. 2017. The Effectiveness Of Using Problem Based Learning (Pbl) In Mathematics Problem Solving Ability For Junior High School Students. IJARIIE. Vol. 3 (2): 3402-3406.

Amir, M.T. 2010. Educational Innovation Through Problem Based Learning, How Educators Empower Students in the Knowledge Age. Jakarta: Kencana Prenada Media Group.

Arends, R.I. 2008a. Learning to Teach. Seventh Edition. Volume 1. (translator of Soedjipto, Helly, P. dan Soedjipto, Sri, M.) Yogyakarta: Pusataka Pelajar.

Das, Ranjan \& Das, Gunendra Chandra. 2013. Math Anxiety: The Poor Problem Solving Factor in School Mathematics. International Journal of Scientific and Research Publication. Vol. 3, Issue 4.

Eggen, P \& Kauchak, D. 2012. Learning Strategies and Models Teaching Content and Thinking Skills. Jakarta : Indeks. Intaros, Pimpaka, et al. 2014. Students Problem Solving Strategies in Problem Solving - Mathematics Clasroom. Elsevier Procedia Social and Behavior Sciences. Vol. 116: 4119-4123.

Liljedahl, P., Santos, M., Malaspina, T.U., \& Bruder, R. 2016. Problem Solving in Mathematics Education. ICME-13 Topical Surveys. Germany: Springer Open.

Muchayat. 2011. Development of Learning Tools with ideal problem-solving strategies with character education. JPP UNES. Vol. 1 (2): 200-203.

Mulyono, A. 2003. Education for Children with Learning Difficulties. Jakarta: Rineka Cipta.

National Council of Teachers of Mathematics. 2000. Principles and Evaluation Standard for School Mathematics. Reston, VA : NCTM.

Ozturk, T. \& Guven, B. 2016. Evaluating Students' Beliefs in Problem Solving Process: A Case Study. Eurasia Journal of Mathematics, Science \& Technology Education, 12(2), 411-429.

Polya, G. 1981. Mathematical Discovery: On Understanding, Learning and Teaching Problem Solving. New York: John Wiley \& Sons, Inc.

Rusman. 2011. Learning Models for Developing Second Edition Teacher Professionalism. Jakarta : Rajawali Press.

Saragih, S. 2007. Developing Logical Thinking Ability and Mathematical Communication of Middle School Students through Realistic Mathematical Approaches. Unpublished dissertation. Bandung: Postgraduate UPI Bandung.

Shapiro, Sharon. 2011. Badger Maths Problem Solving: Skill and strategies for practical problem solving. Great Britain: Badger Publishing.

Sulistyaningsih, Erly. 2013. Development of ICT-based Mathematics Teaching Materials in JJIGSAW Learning Models Differential Material. Fakultas MIPA. IKIP Semarang.

Syahputra, Edi \& Surya, Edy. 2017. The Development of Learning Model Based on Problem Solving to Construct High-Order Thinking Skill on the Learning Mathematics of $11^{\text {th }}$ Grade in SMA/MA. Journal of Education and Practice. Vol. 8 (6): 80-85. 